\title{
Mandibular Osteonecrosis Induced by Bisphosphonates in a Carrier of Chronicle Kidney Disease
}

\author{
Osteonecrosis Mandibular Inducida por Bifosfonatos \\ en un Portador de Enfermedad Renal Crónica
}

\begin{abstract}
Kaohana Thaís da Silva ${ }^{1}$; Greison Rabelo de Oliveira²; Eleonor Álvaro Garbin-Júnior; Natasha Magro-Érnica ${ }^{3}$; Geraldo Griza²; Ricardo Augusto Conci² \& Fabiana Seguin ${ }^{4}$
\end{abstract}

DA SILVA, K. T.; DE OLIVEIRA, G. R. ; GARBIN-JÚNIOR, E. Á.; MAGRO-ÉRNICA, N.; GRIZA, G.; CONCI. R. A. \& SEGUIN, F. Mandibular Osteonecrosis Induced by bisphosphonates in a carrier of chronicle kidney disease. Int. J. Med. Surg. Sci., 4(1):1119-1125, 2017.

SUMMARY: The bisphosphonates are synthetic substances of inorganic pyrophosphate that have been the basis of treatment of patients with osteolytic diseases, such as multiple myeloma, malignant hypercalcemia, Paget's disease, or patients with bone metastases. Its main pharmacological effect is inhibition of bone resorption caused by osteoclasts, which have a reduced function. Their adverse effects are infrequent but include pyrexia, impaired renal function, hypocalcemia, and more recently, maxillo-mandibular ostenecrose induced bofosfonatos. In this report we describe a clinical case of jaw osteonecrosis induced by bisphosphonates in patient with chronic kidney disease and the treatment protocol performed.

KEY WORDS: Jaw osteonecrosis; Bisphosphonates; Chronic kidney disease.

\section{INTRODUCTION}

The bisphosphonates are synthetic substances of the inorganic pyrophosphate which compare to the natural polyphosphate, have been basis, over the last 3 decades, on treatment of carrier patients of osteolytic diseases, as multiple myeloma, malignant hypercalcemia, Paget disease or patients with bone metastasis (Schiødt, 2016).

The main pharmacological bisphosphonates effect is the inhibition of the bone resorption caused by the osteoclasts, which have their function reduced. They also present other secondary effects, as the calcification inhibition on the malignant hypercalcemia treatment, osteoporosis prevention and reduce of the inflammatory reaction of the articulations on the arthritis treatment. $\partial-\sum$. The most powerful, which contain nitrogen, are the N-BPs, represented by alendronate, ibandronate, incandronate, olpadronate, pamidronate, risedronate and zoledronate, while the non-N-BPs, are mainly clodronate, etidronate, and tiludronate (Yamamoto, 2010).

The antiresorption properties of the bisphosphonates increase approximately 10 times between the drugs' generations. Their adverse effects are infrequent, but include pyrexia, problems on the renal function, hypocalcaemia, and, more recently, maxilla-mandibular osteonecrosis induced by bisphosphonates (OIB) (Schiodt; Yamamoto).

${ }^{1}$ Cirurgiã-Dentista, residente em Cirurgia e Traumatologia Bucomaxilofacial da Universidade Estadual do Oeste do Paraná - UNIOESTE / Hospital Universitário do Oeste do Paraná - HUOP, Brasil.

2 Professor assistente do curso de Residência em Cirurgia e Traumatologia Bucomaxilofacial da Universidade Estadual do Oeste do Paraná - UNIOESTE / Hospital Universitário do Oeste do Paraná - HUOP, Brasil.

3 Professor adjunto do curso de Residência em Cirurgia e Traumatologia Bucomaxilofacial da Universidade Estadual do Oeste do Paraná - UNIOESTE / Hospital Universitário do Oeste do Paraná - HUOP, Brasil.

${ }^{4}$ Professora assistente do curso de Odontologia da Universidade Estadual do Oeste do Paraná - UNIOESTE, Brasil. 
The OIB characterizes itself by the incapacity of the bone tissue affected in reparing and reshaping toward inflammatory situations initiated by mechanic stress (chewing), extractions, irritation by prostheses or dental and periodontal infection, taking to the appearance of necrotic bone exposure on the maxillamandibular region (Zanata et al., 2014). They involve individual, complex and challenging treatments, which require antibiotic therapy prolonged, surgeries (Di Fede et al., 2013), hiperbaric oxigen therapy, withing other therapies, that cannot result cure (Di Fede et al.; Zanata et al.).

The present study has the goal to explain a clinic case of mandibular osteonecrosis induced by biophosphonates, in a carrier of chronicle kidney disease, suggesting therapeutic protocol and its implications.

\section{CLINIC CASE}

Patient 66 years old, male, leucoderma, carrier of a chronicle kidney desiase for 9 years, performs peritoneal dialysis three times a day; arthritis rheumatoid historical and hip and acetabulum fracture for 10 years, which includes, besides the rigid intern fixation, the utilization of the medicine Alendronate sodium trihydrate (Bonalen $(\mathbb{)})$, in shape of a $13,06 \mathrm{mg}$ pill once a week during 10 years, following with great roam difficulty, using a wheelchair. He looked for odontological service on the Centro de Especialidades Odontológicas (CEO) of the Universidade Estadual do Paraná (UNIOESTE), due to the presence of intense pain on the right

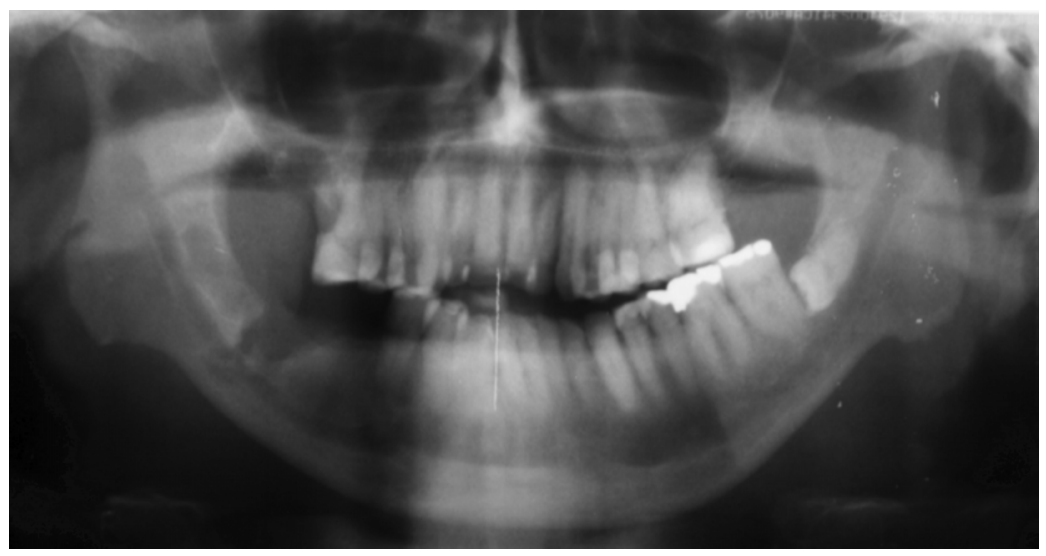

Fig. 1. Panoramic radiograph demonstrating diffuse radiolucent area, corresponding to the alveoli of elements 47 and 48, extracted 2 months ago, without healing aspect compatible with the period. mandibular body, coming after the extraction of the elements 47 and 48 performed 2 months ago. The clinic exam showed, Class II malocclusion, absence of many dental elements, on the region corresponding to the alveolus of the element 47 , suppuration, bone exposure, erythematous edges, on the sot tissues and high touch-sensitive.

The plain radiography revealed poorly radiolucents areas defined on right mandibular body, with the alveolus corresponding to 47 and 48 radiolucents, without the healing aspect waiting fot the period (Fig. 1). The administration of clindamycin $300 \mathrm{mg}$ in $8 / 8$ hours and paracetamol $500 \mathrm{mg}$ in $6 / 6$ hours orally, chlorhexidine $0,12 \%$ use for mouth wash, as an auxiliary way for the oral hygiene started and it was performed the injury incisional biopsy under local anesthesia with Lidocaine $2 \%$ with adrenaline 1:100.000. The Histopathological examination showed bone necrosis and presence of inflammatory infiltrate.

The patient evoluted with pathological fracture on the regian 15 days after the inicisonal biopsy (Fig. 2), he was hospitalized and after the collection for laboratorial tests (complete blood tests, coagulogram, SGOT/SGPT, blood sugar, urea serum levels, ceratinine, potassium, phosphorus, alkaline phosphatase, calcium and sodium) subjected to the surgery to remove the necrotic tissue, corresponding to the elements 47 and 48 elements, with approximately $1,5 \mathrm{~cm}$ and posterior rigid intern fixation with reconstruction system plate $2.4 \mathrm{~mm}$, performed through intra and extraoral submandibular access (Fig. 3), under general anesthesia. He kept hospitalized for 7 days for hospital cares and intravenous antibiotic therapy.

He followed with pre-stipulated medication, only increasing the dose of intravenous Clindamycin for 600 $\mathrm{mg}$ (IV) $6 / 6 \mathrm{~h}$, indication of Tramal $100 \mathrm{mg}$ IV when he felt severe pain. 
The hydro-electrolytic reposition based in $500 \mathrm{~mL}$ of glucose solution in each 12 hours. Liquid and pasty diet and careful oral hygiene was recommended.

After hospital discharge, the patient followed on weekly outpatient monitoring, with significant improvement on complaints, compatible residual repair with the postoperative period; 2 months after the region which before had a necrotic bone exposure presented itself completely closed and without fistulas.

After 8 months of postoperative, it was not observed bone exposure areas or function fail, complaints associated or radio/tomography signal of new areas of OIB (Fig. 4).

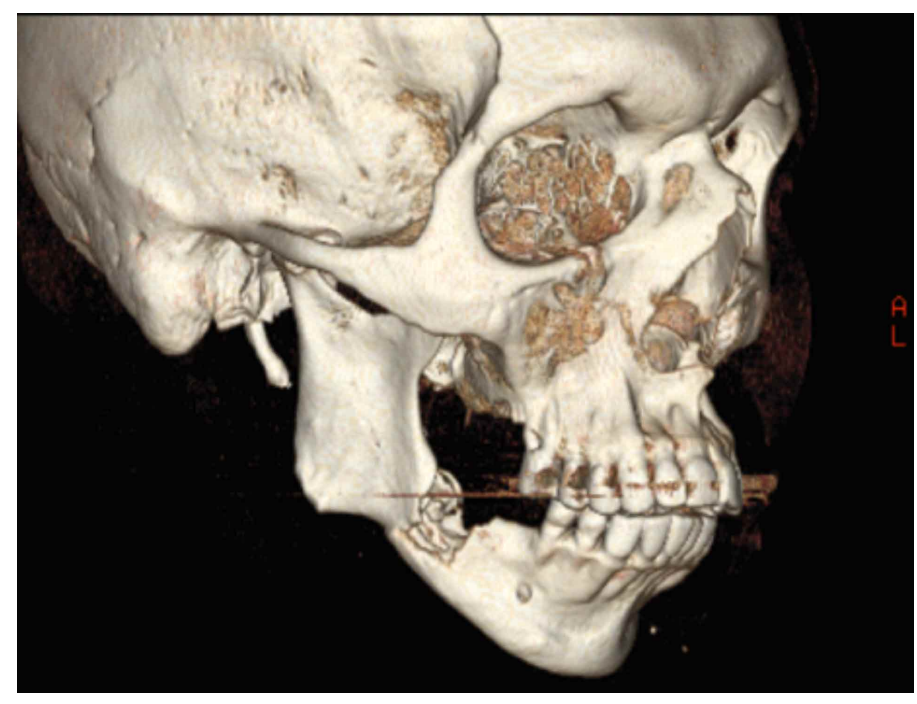

Fig. 2. Tomography showing a pathological fracture in the region of the right mandibular body.
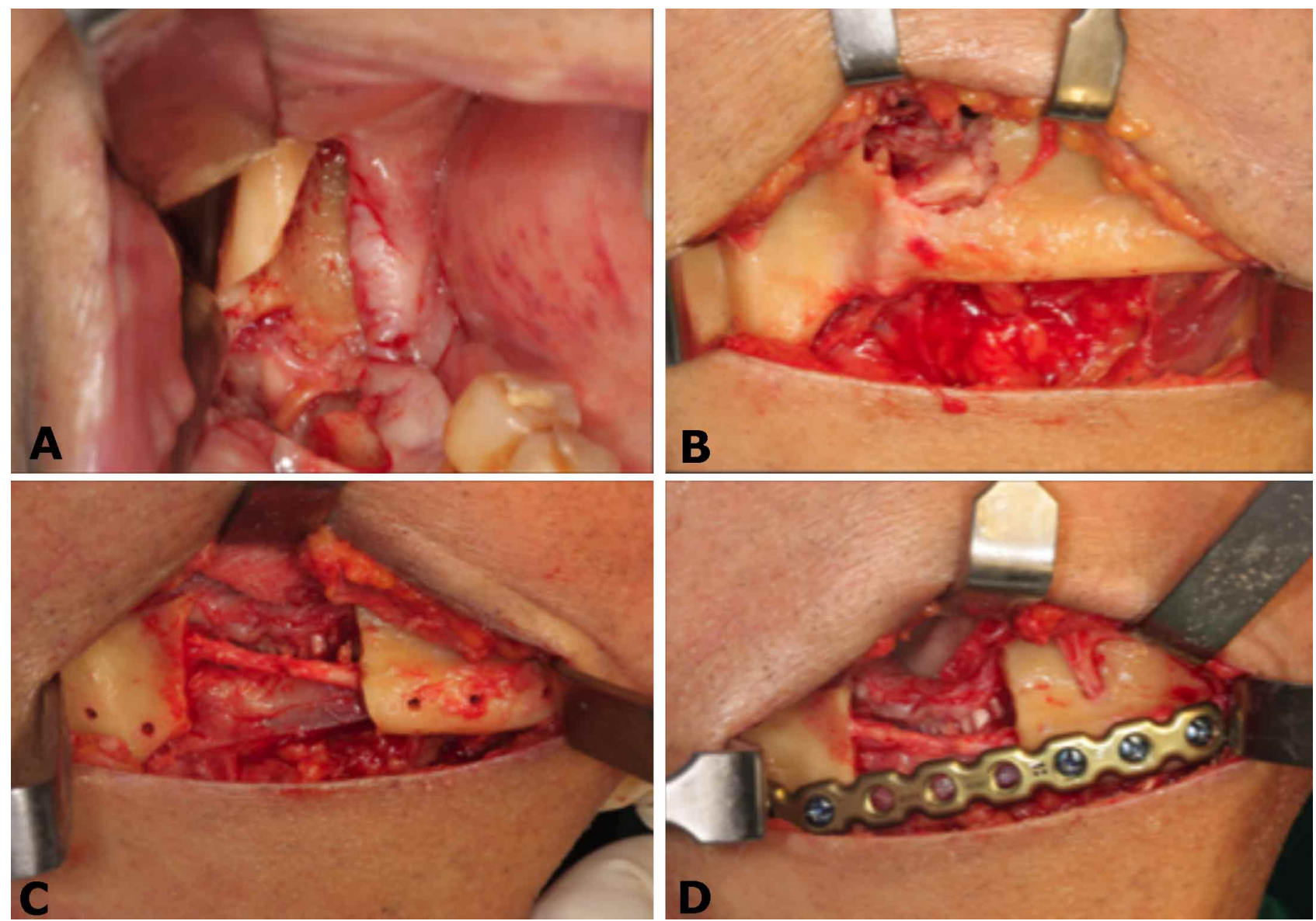

Fig. 3. (A)Intraoral access; (B) Extraoral submandibular access; (C) Removal of necrotic bone tissue with preservation of inferior alveolar nerve, (D) Internal rigid fixation using $2.4 \mathrm{~mm}$ fixation system. 


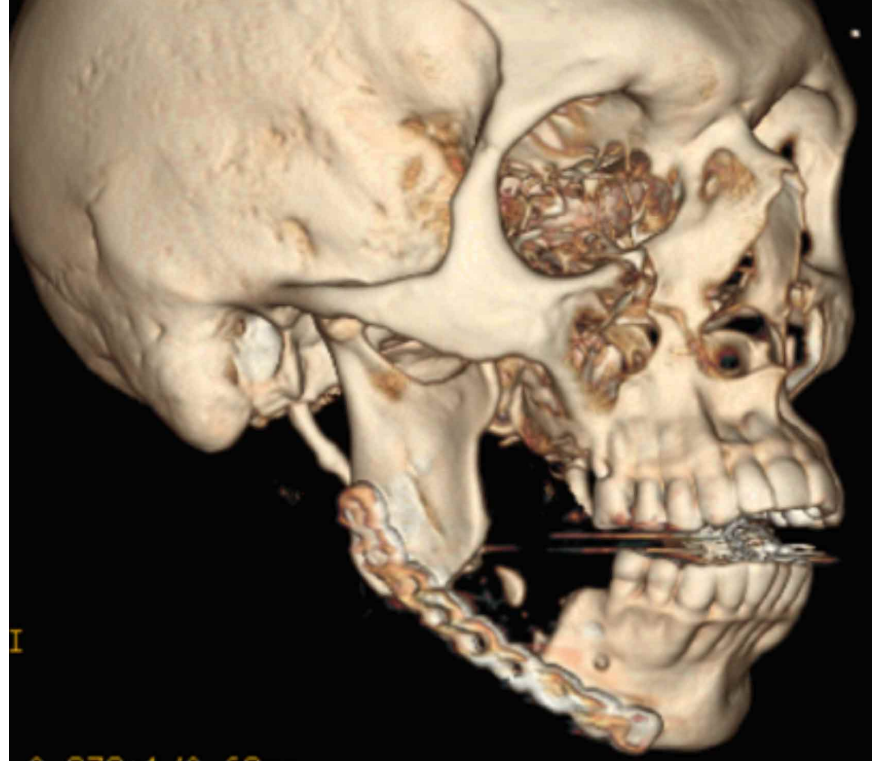

Fig. 4. Tomography with 8 months postoperative, with no evidence of new areas of osteonecrosis.

\section{DISCUSSION}

The bisphosphonates reduce the bone resorption in a dose-dependent manner, mainly when they inhibit the recruitment and promote the osteoclasts apoptosis. Recently, it has been indentified a strong relation between the chronic utilization of these medicines and the maxillamandibular osteonecrosis induced by biphosphonates (OIB) (Yamamoto; Zanata et al.; Schiødt). There are controversies in relation to the diseases' pathogenesis. The greatest bisphosphonates concentration on the maxillary bones can be related to the blood flow and bigger turnover bone in these places, which occurs by the teeth presence and periodontal ligament which demand daily bone remodeling4. However there are claims that the bisphosphonates absorption is not increased on the maxillaries when comparing to other bones (Otto et al., 2010; Zanata et al.) and the pathology occurs on the maxillaries due to the oral cavity microbiota, frequent exposures to the external environment resulting from the odontological surgical procedure, which turn the region more subject to infections (Zanata, et a), and resulting of periodontitis pictures and/or extense carious lesions with endodontic involvement which create acid environments on the mouth cavity, once the bisphosphonates are released on the bone surfaces in acid $\mathrm{pH}$, originating an increase of the local concentration (Otto et $a /$.$) .$

The diagnosis of OIB is defined on the basis of some particularities: current or anterior treatment with bisphosphonates, maxilla-mandibular exposure bone, which persisted for 8 more weeks and absence of radiotherapy history on the maxillaries (Ruggiero et al., 2009).

The risk of developing OIB is not exclusive on patients who receive intravenous bisphosphonates (IV) (Ruggiero et al.). What is observed is that from the bisphosphonates IV administration, zolendronate for example, the average time of osteonecrosis induction can be of only 9 months, while on patients who use oral bisphosphonates, like the alendronate, the average is of 30-52 months (Assael, 2009). Being, the osteonecrosis risk in patients which use oral bisphosphonates, more significant in cases where the treatment duration is longer than 3 years (Ruggiero et al.), datas coinciding with the exposed case.

The OIB, as being a little known pathology, does not have treatment based in standardized orientations yet. The protocol directs itself to each case, depending on the disease stage and systemical condition of the affected patient. It must direct to the elimination or control of the pain, prevention of the exposure bone area progression and remotion of the bone projection which causes soft tissue inflammation and pain, besides closure for first intention of the alveolus after the extractions (Zanata et $a /$.). It has been purposed bone resections, debridements, antibiotic therapy, hyperbaric oxygen therapy, platelet rich plasma, sequestrectomy, local irrigation with antimicrobial solutions, laser therapy, low doses of Parathyroid hormone (PTH) and ozone therapy (Ruggiero et al.; Otto et al.; Zanata et al.). The patient of the present report was treated with rbone resection performed in low rotation by constant irrigation with saline solution $0,9 \%$, in order to avoid heating and increasing of the bone necrosis area; debridements, manipulation and careful soft tissue closure; and intravenous antibiotic therapy for 7 days followed by 2 months orally, rigid oral hygiene and pasty diet. 
The option for the utilization of rigid intern fixation of the system $2.4 \mathrm{~mm}$ must consider GAP bone presence after the resection. On the present case, besides the continuity loss of the bone tissue, the selection of the system $2.4 \mathrm{~mm}$ was done considering the impossibility of bone reconstruction with autogenous bone by the comorbidities related. The fixation system requires specified adaptation of the plate, with attention on the drilling moment, which must be performed under intense irrigation with serum solution $0,9 \%$, with posterior screw installation with minimum stress. Occlusal trauma must be verified and whenever possible corrected, for having decrease of the chewing burden on site. On the present report, it was not possible to perform the occlusal ajust, once the patient did not present the lower molars and had an anterior open bite, the occlusion followed basically in touch to the premolars (Picture).

Always when the patient systemic conditions allow, it must consider the interruption of the oral bisphosphonates during a period of 3 months previously the oral surgery to reduce the osteonecrosis risk, the utilization of the medicine must not be restarted before the bone healing having occurred (Ruggiero et al.; Otto et al.; Di Fede et al.; Zanata, et al.). This approach is based in literature reports which demonstrate relation of the osteoclasts activity with the bisphosphates administrations and showed greater treatment results after the drug suspension. Though the interruption of the bishphosphonates IV does not offer a single benefit in the short-term, however, if the patient systemic conditions allow, the suspension in long-term can be good at the stabilization of osteonecrosis areas, reducing the sintomatology and the OIB development risk in new spots (Zanata, et al.).

On the case reported the patient is a carrier of chronicle kidney disease (CKD). In the preoperative planning of these cases, it's upmost importance the solicitation of laboratory examination. The knowledge of the potassium plasmatic level is fundamental because the hypercalcemia is the most serious nd the most common metabolic alteration seen on preoperative of patients with CKD, and, when not diagnosed, constitutes one of the main death causes on the trans-operative (Medeiros et al., 2015). The sodium levels must be observed, since the hyponatremia can mean dehydration with sodium loss or most frequently, hyperhydration with water excess (Medeiros et al.).

Many times, these patients are anemics, being necessary the solicitation of complete blood count to verify the level of the anaemia and possible leucopenia, since the desnutrition take these patients to the lymphopenia, reduce of the neutrophil activity and worsening of the cellular imunity by the deficiency of amino acids, vitamin B6 and zinc (Filho et al., 2007). It has also been demonstrated the role of the uremic toxins on the leucocytes apoptosis induction. The granulocytes present themselves deficient in many defense functions, such as, chemotaxis, phagocytosis, oxidative metabolism and degranulation. The peripheral mononuclear cells exhibit deficient phagocytosis and reduced capacity of cytokine produce, contributing to the reduction of humoral immunity, lower response to vaccines, reduction of lymphocyte function and reduced capacity of immunoglobulins production (Filho et al.; Medeiros et al.).

The bleed time evaluation (BT) use to be prolonged, although usually the platelets counting, prothrombin time (PT) and the partial thromboplastin time (PTT) present normal values. However, the bleeding can be a significant problem, characterized by a tendency to the prolonged hemorrhage and easily bruses formation. Due to a qualitative platelets defect and not quantitative one, taking to a minor formation of factor III with the inhibition of the platelet aggregation and alteration on the platelet interaction with the endothelium vessels, which cause seems to stem from the biochemical alterations promoted by the uremic toxins (Filho et al.; Medeiros et al.).

It is also indispensable, closely to the laboritory monitoring, to select drugs non nephrotoxics and that, at the same time, performs the required function. To the local anesthesia, it is necessary to give preference to the lidocaine anesthetic, which is metabolized in the liver (Filho et al.; Chidambaram, 2015). In relation to the general anesthesia, with the 
advent of new drugs that are not metabolized or excreted by the kidneys, there's tranquility in the induction, being generally done through thionembutal, fentanyl as analgesic and the atracurium as muscle relaxant, as being metabolized in the plasma (Chidambaram).

Towards the antibiotical medication, it has been given preference to drugs with liver metabolization, as amoxicillin, erythromycin, clindamycin and the metronidazole, and not being recommended tetracycline and aminoglykosides. However, always as possible, the nephrologist must be contacted to the adjustment and choice of the medicine (Chidambaram).

Analgesics, as paracetamol and acetylsalicylic acid, can be used with security in low and moderate doses, but the use must be cautious, when in higher doses. The AINEs must be avoided due to the fluids and sodium retention in the presence of toughest circulatory alterations, besides that it can lead to a exaggerated decline on the kidney function, once it presents nephrotoxicity and inhibit the prostaglandin, as they have an important role on the preservation of renal hemodynamic (Chidambaram).

\section{CONCLUSION}

The lack of a protocol to the OIB treatment, the presence of comorbidities and the necessity of a manual resection with utilization of RIF of the system 2.4 turns the approach on the described case complex, requiring a careful monitoring of the case. The maximum reduction of the chewing stress and the immunocompetence also deserve attention, as they are important factors on the decrease of the appearance of new complications.

DA SILVA, K. T.; DE OLIVEIRA, G. R. ; GARBIN-JÚNIOR, E. Á.; MAGRO-ÉRNICA, N.; GRIZA, G.; CONCI. R. A. \& SEGUIN, F. Osteonecrosis mandibular inducida por bifosfonatos en un portador de enfermedad renal crónica. Int. J. Med. Surg. Sci., 4(1):1119-1125, 2017.

RESUMEN: Los bisfosfonatos son sustancias sintéticas de pirofosfato inorgánico que han sido la base del tratamiento de pacientes con enfermedades osteolíticas, como mieloma múltiple, hipercalcemia maligna, enfermedad de Paget o pacientes con metástasis ósea. Su principal efecto farmacológico es la inhibición de la resorción ósea causada por osteoclastos, que tienen una función reducida. Sus efectos adversos son infrecuentes, pero incluyen pirexia, deterioro de la función renal, hipocalcemia y, más recientemente, indujo inducido por bicosfonatos maxilo-mandibular. En este informe se describe un caso clínico de osteonecrosis mandibular inducida por bifosfonatos en pacientes con enfermedad renal crónica y el protocolo de tratamiento realizado.

PALABRAS CLAVE: Osteonecrosis mandibular; Bisfosfonatos; Enfermedad renal crónica.

\section{REFERENCES}

Assael, L. A. Oral bisphosphonates as a cause of bisphosphonate-related osteonecrosis of the jaws: clinical findings, assessment of risks, and preventive strategies. J. Oral Maxillofac. Surg., 67(5 Suppl.):35-43, 2009.

Chidambaram, R. Optimal Antibiotic Dosage for Chronic Kidney Disease Patient: A Pharmacological Manual for Oral Clinicians. Recent Pat. Antiinfect. Drug Discov., 10(2):113-23, 2015.
Di Fede, O.; Fusco, V.; Matranga, D.; Solazzo, L.; Gabriele, M.; Gaeta, G. M.; Favia, G.; Sprini, D. ; Peluso, F.; Colella, G.; Vescovi, P. \& Campisi, G. Osteonecrosis of the jaws in patients assuming oral bisphosphonates for osteoporosis: a retrospective multi-hospital-based study of 87 Italian cases. Eur. J. Int. Med., 24(8):784-90, 2013.

Filho, J. Z. C.; Padilha, W. S. M. \& dos Santos, E. K. N. Cuidados odontológicos em portadores de insuficiência renal crônica. Rev. Cir. Traumatol. 
DA SILVA, K. T.; DE OLIVeIRA, G. R. ; GARBIN-JúNIOR, E. Á.; MAGRO-ÉRNICA, N.; GRIZA, G.; CONCI. R. A. \& SEGUIN, F. Mandibular osteonecrosis Induced by bisphosphonates in a carrier of chronicle kidney disease. Int. J. Med. Surg. Sci., 4(1):1119-1125, 2017.

Buco-Maxilo-Fac. Camaragibe, 7(2):19-28, 2007.

Medeiros, N. H.; Neves, R. R. A.; Amorim, J. N. C. \& Mendonça, S. M. S. D. A insuficiência renal crônica e suas interferências no atendimento odontológico - Revisão de literatura. Rev. Odontol. Univ. Cid. São Paulo, 26(3):232-42, 2015.

Otto, S.; Hafner, S.; Mast, G.; Tischer, T.; Volkmer, E.; Schieker, M.; Stürzenbaum, S. R.; von Tresckow, E.; Kolk, A.; Ehrenfeld, M. \& Pautke, C. Bisphosphonate-related osteonecrosis of the jaw: is $\mathrm{pH}$ the missing part in the pathogenesis puzzle? J. Oral Maxillofac. Surg., 68(5):1158-61, 2010.

Ruggiero, S. L.; Dodson, T. B.; Assael, L. A.; Landesberg, R.; Marx, R. E.; Mehrotra, B. \& American Association of Oral and Maxillofacial Surgeons. American Association of Oral and Maxillofacial Surgeons position paper on bisphosphonate-related osteonecrosis of the jaws-2009 update. J. Oral Maxillofac. Surg., 67(5 Suppl.):2-12, 2009.

Schiødt, M. Management of Osteonecrosis of the Jaw in Patients Receiving Antiresorptive Treatment. In: Silverman, S. L. \& Abrahamsen, B. (Eds.). The Duration and Safety of Osteoporosis Treatment. Anabolic and Antiresorptive Therapy. 3th ed. New York, Springer International Publishing, 2016. pp.193-202.

Yamamoto, F. P. Estudo da Presença de Osteonecrose na Madíbula após Exodontia de Molares em Ratos Tratados com Alendronato de Sódio. PhD Thesis. São Paulo, Universidade de São Paulo, 2010.

Zanata, A. ; Felin, G. C.; De Bona, M. C.; Sawazaki, R. \& De Conto, F. Osteonecrose mandibular associada ao uso de bisfosfonato de sódio em paciente com mieloma múltiplo. Rev. Port. Estomatol. Med. Dent. Cir. Maxilofac., 55(2):11520, 2014.
Corresponding author: Kaohana Thaís da Silva

Residente em Cirurgia e Traumatologia Bucomaxilofacial do Hospital Universitário do Oeste do Paraná Paraná

BRAZIL

E-mail:kao_thais@hotmail.com

Received: 06-03-2017

Accepted: 17-03-2017 